\title{
THE A-TYPE KERKINI GRANITIC COMPLEX IN NORTH GREECE: GEOCHRONOLOGY AND GEODYNAMIC IMPLICATIONS
}

\author{
Christofides G. ${ }^{1}$, Koroneos A. ${ }^{1}$, Liati A. ${ }^{2}$, and Kral J. ${ }^{3}$ \\ ${ }^{1}$ Aristotle University of Thessaloniki, School of Geology, Department of Mineralogy, Petrology \\ and Economic Geology, 54124 Thessaloniki, Gteece, christof@geo.auth.gr, \\ koroneos@geo.auth.gr, \\ ${ }^{2}$ Institute of Isotope Geology and Mineral Resources, Swiss Federal Institute of Technology \\ (ETH), Clausiusstrasse 25,8092 Zürich.liati@erdw.ethz.ch \\ ${ }^{3}$ Geological Survey, Mlynská dolina 1,81704 Bratislava, Slovak Rrepublic, kral@geology.sk
}

\begin{abstract}
The Kerkini granitic complex (KGC) intrudes the Serbomacedonian massif. KGC comprises the Muries granite (MUR), the Miriofito granite (MIR), and the Kastanusa (KAS) granodiorite. The main rock-type is two-mica granite. Feldspars are represented by albite and perthitic microcline, biotite is iron-rich and white mica is phengite. Fluorite is also present.The rocks are peraluminous, enriched in total alkalis, depleted in $\mathrm{MgO}$ and $\mathrm{CaO}$ and have high $\mathrm{FeOt} / \mathrm{MgO}$ ratios. They are enriched in $\mathrm{Zr}, \mathrm{Nb}, \mathrm{Y}, \mathrm{Ga}$ and $\mathrm{REE}$, and have strong negative Eu anomaly. They plot in the Atype granite fields of various discriminant diagrams and their chemistry suggests a WPG tectonic environment. Sr initial ratio ranges from 0.7107 to 0.7182 . The most probable genetic model is fluid-absent melting of a biotite-rich tonalitic crustal source at $950-975{ }^{\circ} \mathrm{C}$ and at considerable depths. $\mathrm{Rb}-\mathrm{Sr}$ white mica ages and SHRIMP U-Pb zircon ages yielded $246 \pm 3 \mathrm{Ma}$ and $247 \pm 2 \mathrm{Ma}$, respectively, interpreted as the crystallization age of the KGC. K-Ar ages of $130 \pm 3$ and $131 \pm 3 \mathrm{Ma}$ (biotite) and $133 \pm 3 \mathrm{Ma}$ (white mica) can be interpreted by a metamorphic/fluid event at about $133 \mathrm{Ma}$. Rb-Sr white mica dates at $152 \pm 2$ Ma probably resulted by incomplete resetting of the $\mathrm{Rb}-\mathrm{Sr}$ isotopic system and yielded "mixing ages" between crystallization (ca. $247 \mathrm{Ma}$ ) possibly related to a Permian - Triassic rift event and metamorphiclfluid event (ca. $133 \mathrm{Ma}$ ).
\end{abstract}

Key words: A-type granite, SHRIMP, Triassic, rift.

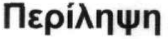

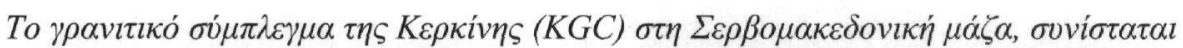

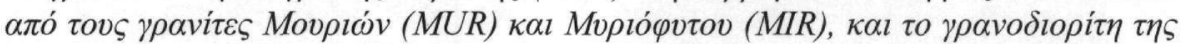

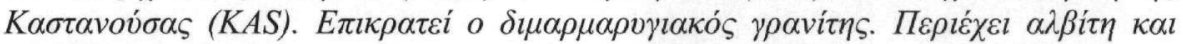

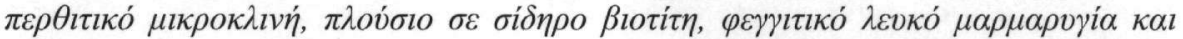

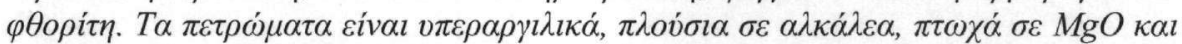

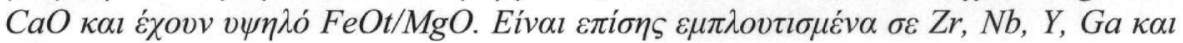




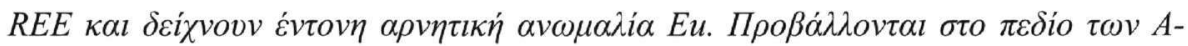

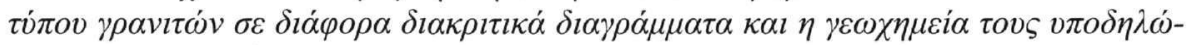

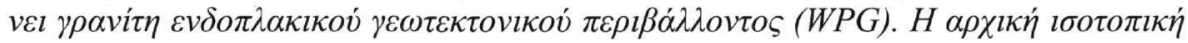

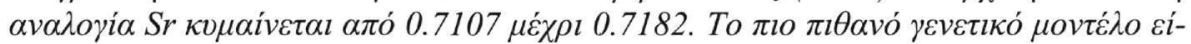

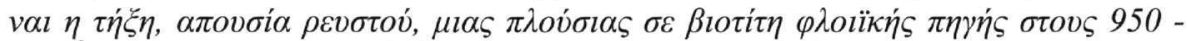

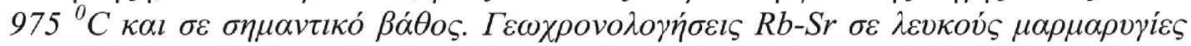

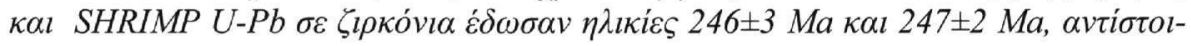

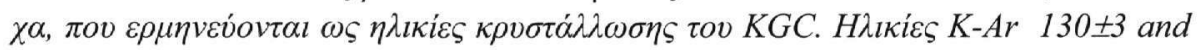

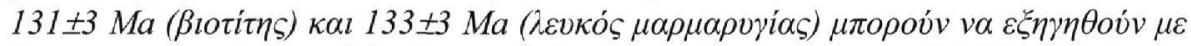

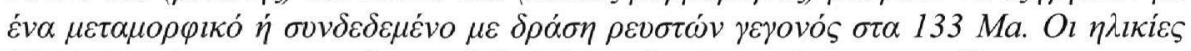

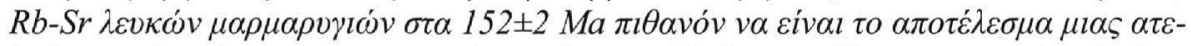

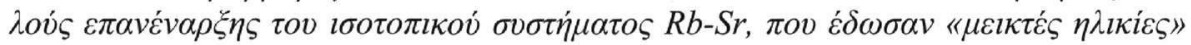

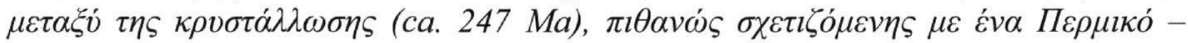

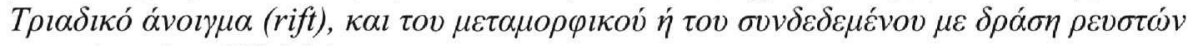

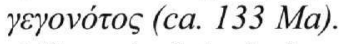

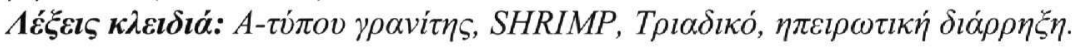

\section{Introduction}

Apart from the two fundamental types of granitic rocks defined by Chappell and White (1974) and White and Chappell (1977), known as S-type and I-type granites, White (1979) defined a third granitoid type (M-type) which was considered as deriving directly from the melting of subducted oceanic crust or the overlying mantle. Another distinctive group of granites has since been designated "A-type" by Loiselle and Wones (1979), who used the term to emphasize the anorogenic tectonic setting, and the relatively alkaline composition as well as the supposedly anhydrous character of the magmas. It was emphasized, however, that unlike the S-, I- and M-type, A-type classification does not imply a specific source or mode of origin. Since then various suggestions and proposals have been made concerning source and mode of origin of A-type granites (Clemens et al. 1986, Whalen et al. 1987, Eby 1990, 1992, Creaser et al. 1991, Skjerlie and Johnston 1993, Landenberger and Collins 1996).

The Serbomacedonian massif (SMM) in northern Greece is characterized by numerous felsic plutonic and volcanic rocks of Permian - Triassic to Tertiary age. The presence of granitoids in a complex geotectonic unit such as the SMM is of particular importance since, through their geochemistry, geochronology and tectonics, they can potentially constrain the timing of the main tectonic events. The detailed study of some of the young (Tertiary) granitoids (Christofides et al. 1990, De Wet et al. 1989) contributed to the reconstruction of the Tertiary geological history in this area.

Among the older intrusions, Arnea granite (de Wet, 1989) and Kerkini granitic complex (KGC) (Christofides et al. 1999, 2000, 2006) are the largest ones. Vital (1987, in Frei, 1992) obtained a $\mathrm{U}-\mathrm{Pb}$ zircon age of $212 \pm 7 \mathrm{Ma}$ for the Arnea granite while Kostopoulos et al. (2001) gave a Pb-Pb

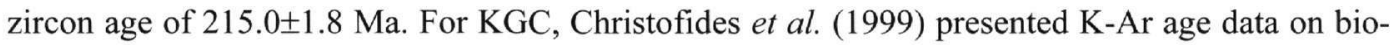
tite and white mica ( $130 \pm 3$ to $133 \pm 3 \mathrm{Ma})$ and interpreted them as representing a metamorphic event rather than the crystallisation age of the complex. Christofides et al. (2006) published new $\mathrm{Rb}-\mathrm{Sr}$ and $\mathrm{U}-\mathrm{Pb}$ datings of Permian/Triassic age. In this paper we investigate the Kerkini granitic complex giving emphasis on its geochronology and its geodynamic significance.

\section{Geological setting}

The SMM in Greece is a complex geotectonic unit which underwent major Permo-Triassic (??) and mid-Mesozoic metamorphic, magmatic and deformational events (Dixon and Dimitriadis 1984, Sakellariou 1989) followed by Eocene and Oligocene/Miocene plutonism (D' Amico et al. 1990, Frei 1992). It extends as a long and narrow zone in a SSE direction from near Belgrade in 
Serbia to the Chalkidiki peninsula in Greece. Based on lithologies and grade of metamorphism it is divided into two units, namely the Kerdyllia unit, a small area in NE Chalkidiki comprising gneisses, amphibolites and marbles metamorphosed under upper amphibolite facies conditions and the Vertiskos unit to the west, which is in tectonic contact with the upper marble horizon of the Kerdyllia unit and comprises various types of gneisses, and amphibolites, metamorphosed under lower amphibolite facies conditions.

The KGC intrudes the NW Vertiskos unit north of Muries village in Mt. Kerkini straddling the Greece - F.Y.R.O.M. border (Fig. 1). It comprises a large intrusion, namely the Muries granite (MUR), an apophysis of the Muries granite to the south, known as the Miriofito granite (MIR) (Sidiropoulos 1991), which is separated from the main granitic body by the Doirani-Kerkini basin, and the Kastanusa (KAS) granodiorite, a small intrusion to the east (Christofides et al. 1999). The country rocks include two-mica and amphibole gneisses, schists and amphibolites. Small outcrops of meta-ultrabasic rocks and marbles are also present. The southern and western contacts of the MUR granite are strongly deformed. Mylonitic fabrics in the granite, especially at the western contact, are well-developed. No contact metamorphism has been observed.

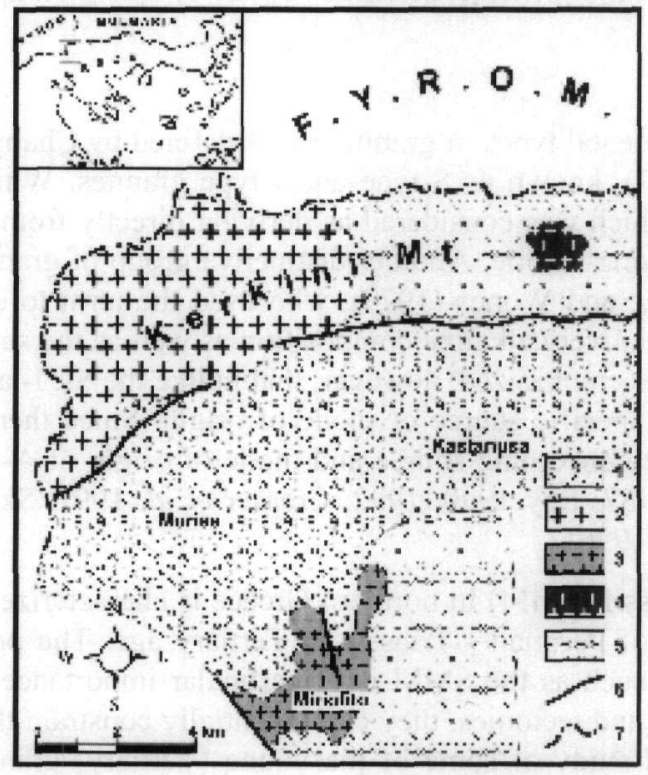

Figure 1 - Geological map of the Kerkini GraniticComplex.

1, Alluvial; 2, MUR; 3, MIR; 4, KAS; 5, Metamorphic basement; 6, Fault; 7, State boundary

\section{Petrography}

The KGC rocks, based on the Q-ANOR diagram (Christofides et al. 1999), are classified as alkali granite to granite (MUR and MIR) and granodiorite (KAS). In most places they are strongly deformed and intensively weathered. MIR is the least deformed granite although hydrothermally altered. The least weathered is the KAS granodiorite which is also the most biotite-rich type. The rocks are medium- to coarse-grained, leucocratic to mesocratic. Fine-grained types with allotriomorphic granular to hypidiomorphic inequigranular textures are also present having subhedral to euhedral perthitic K-feldspar phenocrysts, set in a fine- to medium-grained quartz-feldspathic matrix. The main rock-type is two-mica granite with subordinate biotite and white mica granite (Christofides et al. 1999).

The main mineral constituents are quartz, K-feldspar, plagioclase, biotite and white mica. Accessories include opaques (mostly sulfides), zircon, allanite, apatite, fluorite and titanite. Chlorite, epidote and sericite occur as secondary minerals. Quartz is sometimes recrystallized and forms 
intergrowths with micas. K-feldspar $\left(\mathrm{Or}_{94-98}\right)$, mostly microcline, occurs as perthitic to microperthitic anhedral crystals and as subhedral to euhedral perthitic phenocrysts. Plagioclase is mostly albite and is unzoned (core: $\mathrm{Ab}_{88-99}$, rim: $\mathrm{Ab}_{87-99}$ ), occurring in subhedral to anhedral crystals. Alteration to sericite is not uncommon. Biotite composition is close to annite end-member (Christofides et al. 1999). It is late in the crystallization sequence occurring mostly as interstitial grains between feldspars and quartz. Biotite is frequently altered to chlorite and sometimes to epidote and $\mathrm{Fe}-\mathrm{Ti}$ oxides. The Si content of the white mica ranges from 6.4 to 6.7 (based on $22 \mathrm{O}$ ) and its celadonite component is 22.8-36.8 indicating a phengite-like composition. Microscopically it has features favouring a primary origin (grain size comparable to other primary phases, subhedral form, not enclosed in other minerals). However, such an origin is arguable because of its chemical composition; in terms of $\mathrm{Ti}, \mathrm{Na}$ and $\mathrm{Mg}$, its analysed grains mostly plot in the secondary muscovite field after Miller et al. (1981). Moreover its $\mathrm{TiO}_{2}$ content is $<0.6 \%$ (Zen 1988). It must be stressed here that primary magmatic phengites seem to be very rare. Schleicher and Lippolt (1981) reported a magmatic phengite in felsitic parts of rhyolites from Southwest Germany. Moreover, magmatic phengites were found in a pegmatoid in the area of the Erzgebirge, Saxony (southern Germany) and in a small deformed granitic body in northern Spain (Massonne pers. comm.). The relatively high Si content of the white (magmatic) mica of the Kerkini granite is an indication that crystallization took place at considerable depths.

\section{Methods and materials}

For $\mathrm{Sr}$ isotope analysis, $0.1 \mathrm{~g}$ of sample were digested using concentrated HF and HNO3 (4:1) in Teflon crucibles and taken to dryness. Samples were then digested in $6 \mathrm{M} \mathrm{HCl}$ and centrifuged at $4500 \mathrm{rpm}$ for 30 minutes to remove traces of insoluble residues. Clear solution was removed and taken to dryness again. Natural strontium was eluted through ca $10 \mathrm{ml}$ quartz columns using Biorad AG50W-X8 200-400 mesh resin with 2.5 M HCl. In all steps, pure acids (Merck Suprapure grade) and $18.3 \mathrm{M} \Omega$ water was used. Procedural blank was better then $2 \mathrm{ng}$. Approximately $1 \mu \mathrm{g}$ of $\mathrm{Sr}$ was loaded on Ta filament with $1 \mathrm{M} \mathrm{H}_{3} \mathrm{PO}_{4}$. Strontium isotopic composition was measured in dynamic multicollector mode (100 ratios) on VG Sector 54E thermal ionization mass spectrometer at $1 \mathrm{~V}$ of ${ }^{88} \mathrm{Sr}$ signal. The ${ }^{87} \mathrm{Sr} /{ }^{86} \mathrm{Sr}$ ratio was normalized to ${ }^{86} \mathrm{Sr} /{ }^{88} \mathrm{Sr}=0.1194$. During period of analyses, SRM-987 yielded a grand mean ${ }^{87} \mathrm{Sr} /{ }^{86} \mathrm{Sr}$ ratio $=0.710236 \pm 14-0.710262 \pm 17$ and all ${ }^{87} \mathrm{Sr} /{ }^{86} \mathrm{Sr}$ ratios in Table 2 were adjusted to value of SRM-987 $=0.710248$.

The U-Pb zircon data were obtained on SHRIMP II at the Geological Survey of Canada, Ottawa. The spot size was ca. $20 \mu \mathrm{m}$ in diameter. For data collection, seven scans through the critical mass range were made. $\mathrm{U} / \mathrm{Pb}$ ratios were calibrated relative to standard BR266. For details on the SHRIMP technique see Stern (1997) or Williams (1998). Data were corrected for common $\mathrm{Pb}$ using the ${ }^{207} \mathrm{~Pb}$ correction method (see Williams 1998). Cathodoluminescence (CL) images of the zircons revealed that the ca. $200 \mu \mathrm{m}$ long euhedral crystals are composed largely of a single domain with oscillatory zoning (Fig. 2).

\section{Geochemistry}

Major and trace element analyses of 18 selected samples from all rock-types were determined by XRF. Six of them were analysed for REE and some trace elements by INAA. Chemical data of the analysed samples as well as major, trace and rare earth element compositional variations are presented by Christofides et al. (1999). Here, only some critical geochemical characteristics will be reported. The $\mathrm{SiO}_{2}$ content of the KGC ranges between 69 and $76 \mathrm{wt} \%$. Total alkalis are high, ranging from 8.2 to $9.5 \mathrm{wt} \%$ while $\mathrm{CaO}$ is $<1.5 \mathrm{wt} \%$ and in most samples $<0.7 \mathrm{wt} \%$. Although $\left(\mathrm{Na}_{2} \mathrm{O}+\mathrm{K}_{2} \mathrm{O}\right) / \mathrm{Al}_{2} \mathrm{O}_{3}$ is high, none of the rocks is peralkaline. $\mathrm{FeO} / \mathrm{MgO}$ ratio ranges from 6.2 to 19.1. The rocks are in general enriched in $\mathrm{Zr}, \mathrm{Nb}, \mathrm{Ga}, \mathrm{Rb}, \mathrm{Y}, \mathrm{Th}$ and $\mathrm{U}$. The $\mathrm{Y} / \mathrm{Nb}$ ratio in the KGC ranges from 2.4 to 4.3 and it remains constant with $\mathrm{SiO}_{2}$ increase. The REE patterns of all samples are similar and quite enriched relative to chondrite $\left(\mathrm{La}_{\mathrm{CN}}=150-220\right)$ but with slight LREE 
enrichement $\left[(\mathrm{La} / \mathrm{Lu})_{\mathrm{CN}}=3-6\right]$. $\Sigma$ REE ranges from 214 to $315 \mathrm{ppm}$. The REE patterns show a large negative $\mathrm{Eu}$ anomaly $\left(\mathrm{Eu} / \mathrm{Eu}^{*}=0.06-0.30\right)$ which increases with increasing $\mathrm{Sr}$ content.

Compared with the MUR granite the KAS granodiorite shows a few differences. The most notable ones are the higher $\mathrm{Al}_{2} \mathrm{O}_{3}$ and $\mathrm{Na}_{2} \mathrm{O}$ contents and the significantly lower $\mathrm{K}_{2} \mathrm{O}$ content in the granodiorite. Its trace elements are also different particularly, $\mathrm{V}, \mathrm{Nb}, \mathrm{Zr}, \mathrm{Y}, \mathrm{Rb}, \mathrm{Ba}$ and $\mathrm{Sr}$. The KAS REE pattern is similar to those of MUR in respect to LREE enrichement $\left[(\mathrm{La} / \mathrm{Lu})_{\mathrm{CN}}=3.5\right]$ but shows smaller $\mathrm{Eu}$ anomaly $\left(\mathrm{Eu} / \mathrm{Eu}^{*}=0.62\right)$ and is less enriched relative to chondrite $\left(\mathrm{La}_{\mathrm{CN}}=100\right)$. Moreover its $\Sigma$ REE is significantly lower $(150 \mathrm{ppm})$. Probably the KAS granodiorite represents a different intrusion and thus it is not considered further.

The MIR granite follows in general the MUR oxide trends. However, it is distinguishable in terms of $\mathrm{Al}_{2} \mathrm{O}_{3}, \mathrm{CaO}, \mathrm{Nb}, \mathrm{Zr}$ and $\mathrm{Y}$. Its REE patterns is similar to those of MUR granite with small slope $\left[(\mathrm{La} / \mathrm{Lu})_{\mathrm{CN}}=3.3\right]$ and strong negative $\mathrm{Eu}$ anomaly $\left(\mathrm{Eu} / \mathrm{Eu}^{*}=0.15\right)$. MIR, however, is significantly poorer in REE compared to MUR at the same $\mathrm{SiO}_{2}$ content $\left(\mathrm{La}_{\mathrm{CN}}=132, \Sigma \mathrm{REE}=197 \mathrm{ppm}\right)$. The rocks analysed are peraluminous in terms of $\mathrm{A} / \mathrm{CNK}$ molar ratio which ranges between 1.0 and 1.3. Only one sample has $\mathrm{A} / \mathrm{CNK}=0.8$.

$\mathrm{Sr}$ initial ratio is relatively high ranging from 0.7107 to 0.7182 based on $247 \mathrm{Ma}$ (see below).

\section{Geochronology}

Various geochronological methods (K-Ar, Rb-Sr on micas, whole-rock Rb-Sr, SHRIMP zircon U$\mathrm{Pb}$ ) have been applied to accurately define the crystallization age of KGC and any postcrystallization metamorphic/fluid event. Christofides et al. (1999) reported K-Ar ages on biotite of $130 \pm 3$ and $131 \pm 3 \mathrm{Ma}$ and on white mica of $133 \pm 3 \mathrm{Ma}$. U-Pb SHRIMP radiometric data on zircon and $\mathrm{Rb}-\mathrm{Sr}$ whole-rock and micas data are given in Tables 1 and 2 respectively.

Table 1 - U, Th, Pb SHRIMP data for magmatic zircon domains from KGC

\begin{tabular}{|c|c|c|c|c|c|c|c|c|}
\hline Sample & $\mathbf{U}$ & Th & $\mathbf{T h} / \mathbf{U}$ & $\mathbf{P b}^{*}$ & $\mathbf{f}_{206} \mathrm{~Pb}$ & $\begin{array}{c}{ }^{207} \mathrm{~Pb} /{ }^{206} \mathrm{~Pb} \pm \text { error } \\
\text { (uncorrected) }\end{array}$ & $\begin{array}{c}{ }^{238} \mathrm{U} /{ }^{206} \mathrm{~Pb} \pm \text { error } \\
\text { (uncorrected) }\end{array}$ & $\begin{array}{l}\text { Age } \pm \text { er- } \\
\text { ror } \\
\text { (Ma) }\end{array}$ \\
\hline MP501-7.1 & 1050 & 1014 & 0.998 & 49 & 0.001 & $0.0520 \pm 0.0005$ & $25.13 \pm 0.27$ & $251.3 \pm 2.7$ \\
\hline MP501-19.1 & 223 & 157 & 0.727 & 9 & 0.007 & $0.0565 \pm 0.0012$ & $25.44 \pm 0.32$ & $247.0 \pm 3.0$ \\
\hline MP501-28.1 & 118 & 60 & 0.521 & 5 & 0.019 & $0.0663 \pm 0.0016$ & $25.70 \pm 0.36$ & $241.5 \pm 3.4$ \\
\hline MP501-30.1 & 490 & 335 & 0.705 & 21 & 0.005 & $0.0549 \pm 0.0007$ & $25.52 \pm 0.28$ & $246.6 \pm 2.7$ \\
\hline MP501-26.1 & 220 & 119 & 0.558 & 9 & 0.007 & $0.0569 \pm 0.0010$ & $25.55 \pm 0.33$ & $245.7 \pm 3.1$ \\
\hline MP501-22.1 & 535 & 160 & 0.308 & 20 & 0.004 & $0.0545 \pm 0.0010$ & $25.44 \pm 0.28$ & $247.5 \pm 2.7$ \\
\hline \multicolumn{7}{|c|}{$\begin{array}{l}\text { Notes: } 1 . \mathrm{Pb}^{*} \text { is radiogenic } \mathrm{Pb} ; 2 . \mathrm{f}_{206} \mathrm{~Pb} \text { denotes the percentage } \\
\text { of }{ }^{206} \mathrm{~Pb} \text { that is common } \mathrm{Pb} ; \mathbf{3} \text {. WM: weighted mean (error on } \\
\text { the } \mathrm{WM} \text { is at the } 95 \% \text { c.l.); } 4 \text {. } \pm \text { error is at } 1 \text { sigma level. }\end{array}$} & \multicolumn{2}{|c|}{ WM: $247.0 \pm 2.3 \mathrm{M}$} \\
\hline
\end{tabular}

Cathodoluminescence (CL) images of the zircons revealed that the ca. $200 \mu \mathrm{m}$ long euhedral crystals are composed largely of a single domain with oscillatory zoning (Fig. 2), indicating that they precipitated from a melt. The fact that the zircon crystals consist of a single (magmatic) domain argues against an S-type origin for the Kerkini granite, since zircons from S-type granites have, in their majority, inherited cores. Most zircon crystals separated from the Kerkini granite show in CL thin bright (U-poor) domains either at the outermost margins of the crystals or on either side of fractures (Fig. 2). 
These CL bright domains are probably the result of post-crystallization action of fluids, related to a metamorphic/deformational event. The development of such thin metamorphic rims on zircon indicates low grade of metamorphism (usually below ca. $600{ }^{\circ} \mathrm{C}$ ) and/or low amounts of fluids. The data are graphically presented on a Tera-Wasserburg diagram (Tera and Wasserburg 1972), uncorrected for common $\mathrm{Pb}$. Six data points on six different zircon crystals plot on a mixing line with common $\mathrm{Pb}$ and calibrated total ${ }^{238} \mathrm{U} /{ }^{206} \mathrm{~Pb}$ as end members (Fig. 3). The weighted mean age of these analyses is $247.0 \pm 2.3 \mathrm{Ma}$ (MSWD=1.1; error on the $95 \% \mathrm{c} .1$.). This age is interpreted to reflect the crystallisation time of the $\mathrm{KGC}$. It was not possible to get $\mathrm{U}-\mathrm{Pb}$ data for the postcrystallization, metamorphic/deformational event affecting this granite due to the small thickness of the metamorphic domains of the zircons (Fig. 2), in combination with their very low U content.
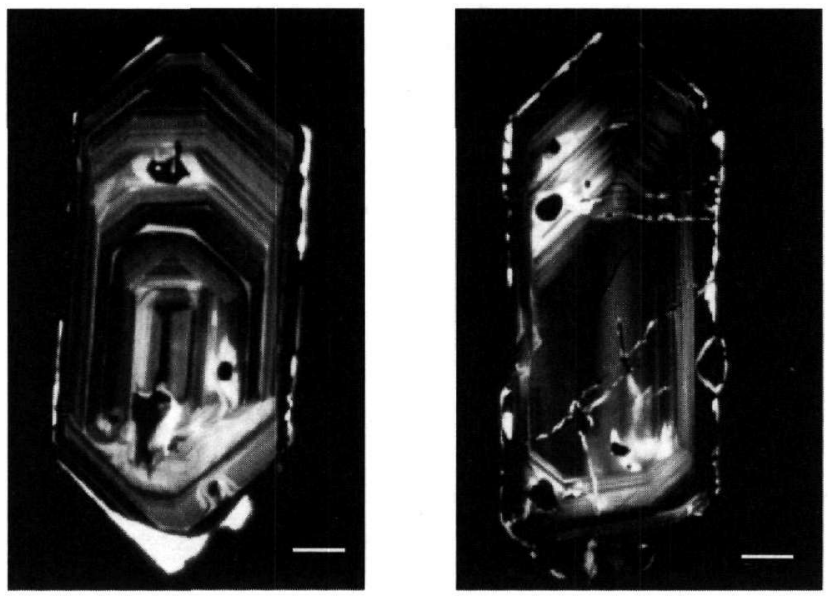

Figure 2 - Cathodoluminescence images of representative zircon crystals from the KGC showing oscillatory zoning, typical for co-magmatic zircons. Note the bright thin rims (broadest at the bottom of the left-side crystal) and fractures (right-side crystal) indicative of post-crystallization interaction with fluids (see text). White bars are 20 microns

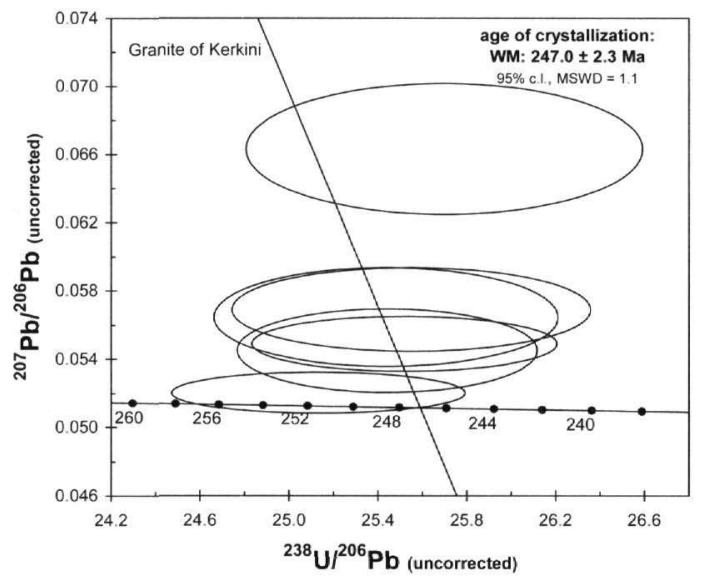

Figure 3 - Tera-Wasserburg plot with data from the KGC

Six representative whole-rock samples were analyzed for $\mathrm{Sr}$ isotopes. Using all data an age of $259 \pm 12$ can be obtained with an MSWD value equal to 18 (Fig. 4a). Due to this high MSWD value the regression line can be interpreted as errorchorn rather than isochron. Using five of the six samples (excluding MP-100 although no petrological reason exists) a quite similar age of $259.0 \pm 7.8$ $\mathrm{Ma}$ is calculated but with a significantly lower MSWD value of 6.4 (Fig. 4b). Taking into account 
the number of samples, the latter MSWD value allows us to interpret this line as representing an isochron. The $259 \pm 12 \mathrm{Ma}$ or $259.0 \pm 7.8 \mathrm{Ma} \mathrm{Rb} / \mathrm{Sr}$ age is, within uncertainty, in line with the $247.0 \pm 2.3 \mathrm{Ma} \mathrm{U}-\mathrm{Pb}$ SHRIMP age interpreted as the time of crystallisation of the granite. Wholerock - biotite pair gave $137 \mathrm{Ma}$ while two whole-rock - white mica pairs gave 152 and $246 \mathrm{Ma}$ (Table 2).

\section{Tectonic setting}

The major element geochemistry of the KGC rocks is consistent with late-orogenic and anorogenic granitoids as defined by Batchelor and Bowden (1985) (Christofides et al. 1999). Moreover KGC rocks plot in the within-plate granites (WPG) field of Pearce et al. (1984) diagrams, showing that their genesis is very probably related to a WPG tectonic setting. However, the characteristic geochemical features of KGC could also be related to its source material rather to a specific tectonic setting.
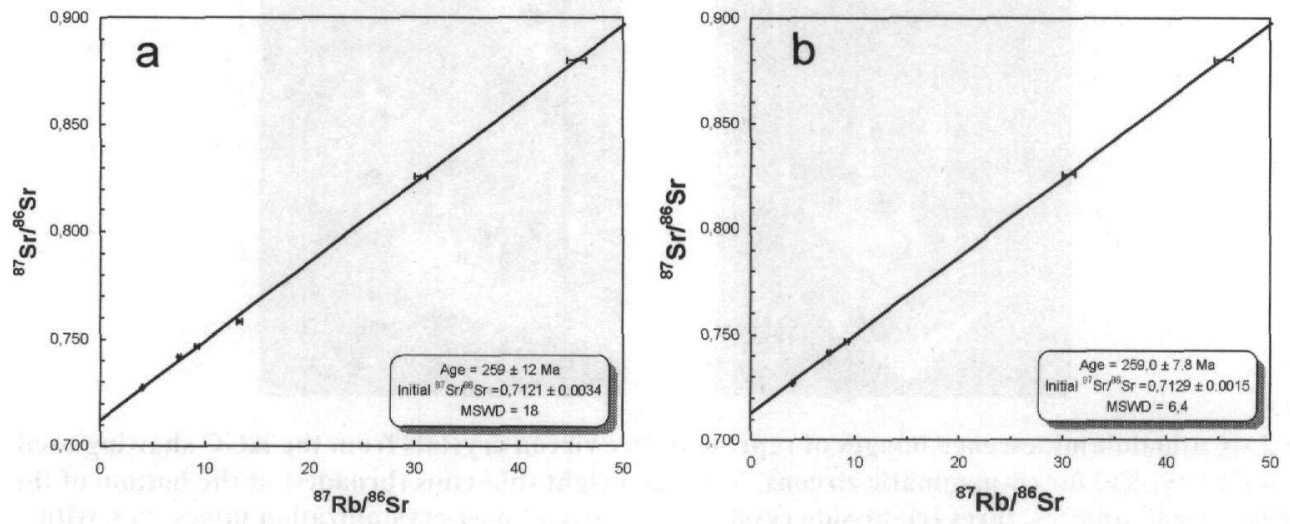

Figure 4 - Rb-Sr whole-rock 6-point errorchron (a) and 5-point isochron for the KGC

Table 2 - Whole-rock and micas Rb-Sr isotopic data for the KGC

\begin{tabular}{|l|r|r|r|r|r|r|r|r|r|}
\hline Sample & & $\mathbf{R b}$ & $\mathbf{S r}$ & ${ }^{87} \mathbf{R b} /{ }^{86} \mathbf{S r}$ & ${ }^{87} \mathbf{S r} /{ }^{86} \mathbf{S r}$ & $\begin{array}{r}\mathbf{2 \sigma} \\
\mathbf{a b s}\end{array}$ & $\left({ }^{87} \mathbf{S r} /{ }^{86} \mathbf{S r}\right)_{\mathbf{0}}$ & $\begin{array}{c}\text { Age } \\
\text { (Ma) }\end{array}$ \\
\hline MP-100 & wr & 178.3 & 38.9 & 13.3267 & 0.758068 & 38 & 0.7107 & 9 & \\
\hline MP-100 & bt & 902.2 & 8.8 & 316.0 & 1.34618 & 2 & & & $136.7 \pm 1.4$ \\
\hline MP-103 & wr & 46.0 & 33 & 4.0407 & 0.727195 & 36 & 0.7128 & 3 & \\
\hline MP-103 & wm & 173.0 & 8.0 & 65.35 & 0.94140 & 7 & & & $245.6 \pm 2.6$ \\
\hline MP-104 & wr & 112.5 & 43.3 & 7.5420 & 0.741513 & 37 & 0.7147 & 5 & \\
\hline MP-104 & wm & 424.1 & 6.7 & 190.3 & 1.13712 & 3 & & & $152.2 \pm 1.6$ \\
\hline MP-114 & wr & 124 & 39 & 9.2343 & 0.746810 & 37 & 0.7140 & 7 & \\
\hline MP-105 & wr & 220 & 21 & 30.6608 & 0.825900 & 41 & 0.7169 & 22 & \\
\hline MP-23 & wr & 201 & 13 & 45.4883 & 0.880010 & 44 & 0.7182 & 32 & \\
\hline
\end{tabular}

Error on ${ }^{87} \mathrm{Rb} /{ }^{86} \mathrm{Sr}$ is $1 \%$; wr, whole-rock; bt, biotite; wm, white mica. 


\section{Origin}

The plot of the KGC in the WPG field of Pearce et al. (1984) discriminant diagram (see Christofides et al. 1999) is an indication that it is related with A-type granite magmatism (Pearce et al. 1984, Whalen et al. 1987, Eby 1990). In fact the Kerkini granitic complex has features characteristic for A-type granites as these have been described by many authors for various suites of such type e.g. Collins et al. (1982), Whalen et al. (1987), Eby (1990), Landenberger and Collins (1996), Mohamed et al. (1999). In particular the rocks investigated: are peraluminous, are depleted in $\mathrm{MgO}$ and $\mathrm{CaO}$, enriched in total alkalis and they have high $\mathrm{FeOt} / \mathrm{MgO}$ ratios, are enriched in $\mathrm{Zr}$, $\mathrm{Nb}, \mathrm{Y}, \mathrm{Ga}$ and REE, they have strong negative Eu anomaly and they contain iron-rich interstitial biotite (annite), and fluorite, indicating dry or almost anhydrous melts with elevated fluorine content.

Moreover the KGC samples fall in the A-type granite field of Whalen et al. (1987) discriminant diagrams (see Christofides et al. 1999) and of Eby's (1990) discriminant diagrams FeOt/MgO and $10000 * \mathrm{Ga} / \mathrm{Al}$ vs $\mathrm{Zr}+\mathrm{Nb}+\mathrm{Ce}+\mathrm{Y}$ (Figs $5 \mathrm{a}, \mathrm{b}$ ).
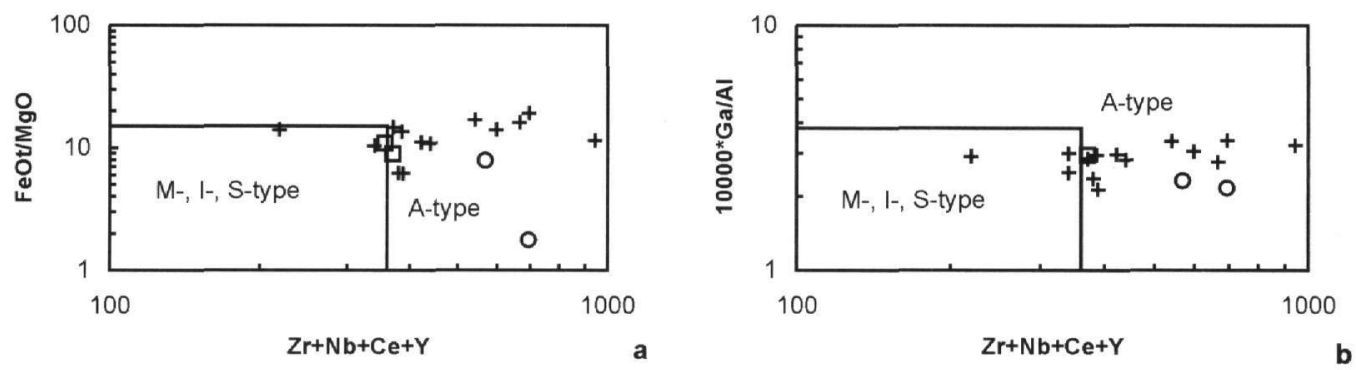

\section{Figure 5 - Plot of the KGC samples on the Eby's (1990) discrimination diagrams. Cross, MUR; circle, KAS; rectangle, MIR}

Several mechanisms have been considered for the genesis of A-type magmas. The most credible genetic model involves high temperature partial melting of melt-depleted I-type source rocks (a granulitic residue) in the lower continental crust (Collins et al. 1982, Clemens et al. 1986, Whalen et al. 1987). In such a model, melting would probably involve fluid-absent breakdown of residual, halogen-enriched micas and amphiboles and the melts would be relatively water poor. The genesis of A-type granites has also been explained by partial melting of non-restitic crustal igneous rocks of tonalitic to granodioritic composition at mid-crustal pressures (Creaser et al. 1991, Skjerlie and Johnston 1993). An alternative model for the origin of A-type granites involves partial melting of a lower-crustal source that was dehydrated, but not geochemically depleted (Landenberger and Collins 1996).

Fluid-absent melting experiments on a biotite $(20 \mathrm{wt} \%)$ and hornblende $(2 \mathrm{wt} \%)$ bearing tonalitic gneiss (sample AGC150) were conducted by Skjerlie and Johnston (1993) at $6 \mathrm{kbar}\left(900-975{ }^{\circ} \mathrm{C}\right)$, $10 \mathrm{kbar}\left(875-1075{ }^{\circ} \mathrm{C}\right)$ and $14 \mathrm{kbar}\left(950-975^{\circ} \mathrm{C}\right)$ to study melt productivity from weakly peraluminous quartz-feldspathic metamorphic rocks. These experiments showed that the dehydrationmelting of F-enriched biotite source produces F-rich granitic liquids with compositions within the range of A-type granites leaving behind a granulitic residue dominated by orthopyroxene, quartz and plagioclase. Initiation of dehydration melting is caused by intrusion of hot, mantle-derived magmas into the lower crust.

A crustal origin for the KGC is supported by its relatively high $\mathrm{Sr}$ initial ratio (0.7107-0.7182 based on $247 \mathrm{Ma}$ ) and its $\mathrm{Y} / \mathrm{Nb}$ ratio (2.4 to 4.3) which falls within the range 1.2-7 for which Eby (1990) considered a crustal involvement in magma genesis. The majority of the KGC samples which plot on the A - B diagram of Debon and Le Fort (1983) fall in the field defined by the experimental liquids of Skjerlie and Johnston (1993) in particular where the liquids were produced at 
6 - 10 kbar and $950-975{ }^{\circ} \mathrm{C}$ (see Christofides et al. 1999). Note the dispersion of the KAS granodiorite in the above field. Therefore, a similar source and a similar mechanism would give the Kerkini granites. It is worth mentioning that the internal structure of the zircons (lack of inherited cores; a single magmatic oscillatory zoning domain) strongly argues against a possible metasedimentary source for the genesis of this granite. The presence of plagioclase in the residue could explain both their strongly negative $\mathrm{Eu}$ anomaly and their low $\mathrm{Sr}$ content. Hence, the most probable genetic model for the origin of the $\mathrm{KGC}$ is fluid-absent melting of a biotite-rich tonalitic source at $950-975{ }^{\circ} \mathrm{C}$ and, due to the high Si content of white mica, at considerable depths, leaving a granulitic residue dominated by orthopyroxene, quartz and plagioclase (Christofides et al. 1999).

\section{Discussion - conclusions}

The $247.0 \pm 2.3 \mathrm{Ma}$ age obtained by SHIRMP on zircon crystals, supported also by the $\mathrm{Rb}-\mathrm{Sr}$ whole rock age ( $259 \pm 12 \mathrm{Ma}$ or $259.0 \pm 7.8$ $\mathrm{Ma})$, is considered as the crystallisation age of the granite and places its genesis in the Late Permian/Early Triassic boundary. The identical $246 \pm 3 \mathrm{Ma} \mathrm{Rb}-\mathrm{Sr}$ age on white mica of $\mathrm{KGC}$, is also interpreted as the crystallisation age (Fig. 6). It seems that white mica has at least partly kept its magmatic signature implying that the metamorphism affecting the granite was of relatively low grade allowing white mica to escape total recrystallisation and total resetting of the $\mathrm{Rb}-\mathrm{Sr}$ system. This is in accordance with the development of very thin metamorphic domains of the zircons, as well as with petrological observations.

The K-Ar ages on micas and the $\mathrm{Rb}-\mathrm{Sr}$ age on biotite can be interpreted by a metamorphic/fluid event at about $133 \mathrm{Ma}$. K-Ar and $\mathrm{Rb}-\mathrm{Sr}$ mica ages of 102 to $131 \mathrm{Ma}$

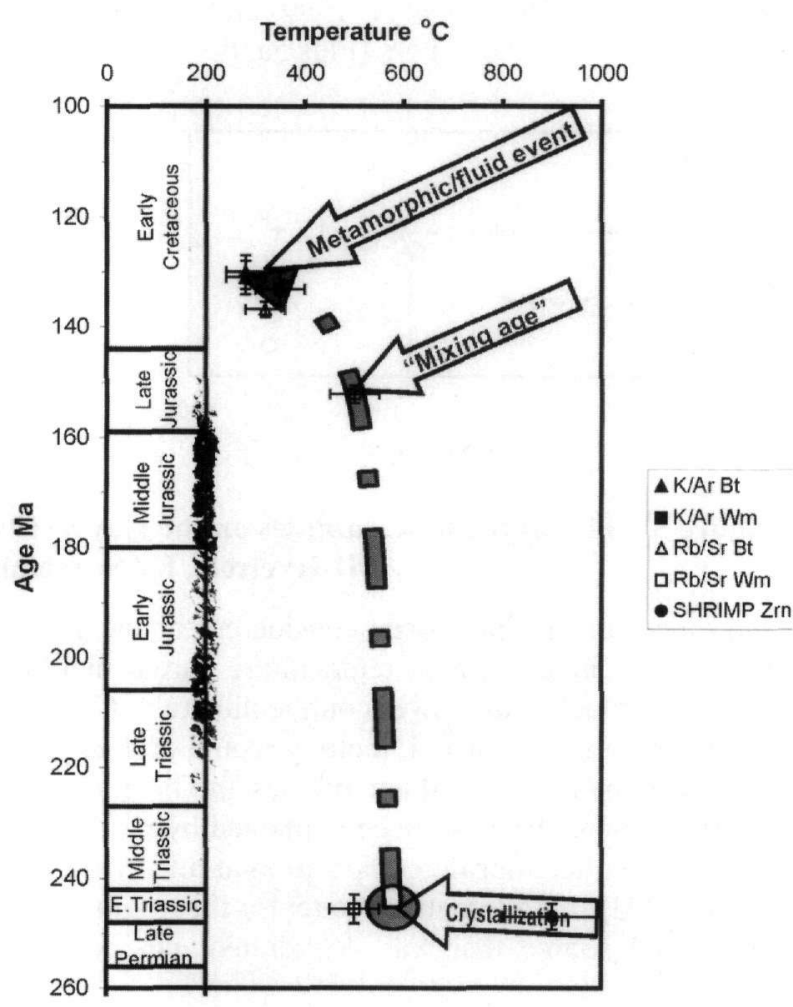

Figure 6 - Plot of mineral age vs. blocking temperature fot the KGC rocks

obtained from Vertiscos rocks were interpreted (Papadopoulos and Kilias 1985) to reflect a retrograde and deformation event or a lower Cretaceous rejuvenation (Frei 1992). The last event was considered by Sakellariou (1989) equal to the regional lower amphibolite facies metamorphic event responsible for the main structural overprint in the SMM rocks. The $152 \pm 2 \mathrm{Rb}-\mathrm{Sr}$ white mica date could be considered as a "mixing age" between the crystallization age of the granite (ca. $247 \mathrm{Ma}$ ) and the metamorphic/fluid event (ca. $133 \mathrm{Ma}$ ). This "mixing age" very probably reflects partial resetting of the $\mathrm{Rb}-\mathrm{Sr}$ white mica isotopic system. The same is true for the $137 \mathrm{Ma} \mathrm{Rb}-\mathrm{Sr}$ biotite age (Fig. 6).

The Late Permian/Eearly Triassic KGC is a WPG with A-type granite characteristics. Its $\mathrm{Sr}$ initial ratio, ranging between 0.7107 and 7182 (based on $247 \mathrm{Ma}$ ) reflects the high contribution of crustal 
material for the magma genesis. The most probable genetic model for the origin of KGC is fluidabsent melting of a biotite-rich tonalitic source at $6-10 \mathrm{kbar}$ and $950-975{ }^{\circ} \mathrm{C}$, leaving behind a granulitic residue dominated by orthopyroxene, quartz and plagioclase (Christofides et al. 1999).

The A-type characteristics of KGC and its WPG tectonic setting is in favour of a rift-related genesis although its A-type characteristics could also be related to its source material, having a peculiar composition or even to a post-collisional tectonic setting (cf. Eby 1992, Wu et al. 2002, Zhou 2006) although a clear distinction between rift-related and post-collisional A-type granites is not well documented. A rift responsible for several magmatic events in the broader area has been suggested by many researchers (cf. Pe-Piper and Piper 2002 and references therein). De Wet (1989) suggested a rift event to which he ascribed the magmatism that gave the Arnea granite. A rift event is also considered responsible, by Kostopoulos et al. (2001), for the Arnea granite, which although younger $(215.0 \pm 1.8 \mathrm{Ma})$ than KGC shows many geochemical similarities (Christofides et al. 2000). Moreover, Dimitriadis and Asvesta (1993) considered most of the "volcano-sedimentary" series as related to a Permian - Triassic rift. Hence, it is concluded that the genesis of KGC is very probably related to the Permian - Triassic event that affected the broader area. It is noted that in W. and E. Rhodope, eclogites of Upper Permian protolith ages, indicating a rift-related setting are also reported (Liati and Fanning 2005). Finally, poly-episodic Permo-Triassic rifting, indicated by different thermal pulses of mainly felsic but also mafic magmas in this time period, is also a general feature commonly identified in Western Europe.

\section{Acknowledgements}

G. Christofides and A. Koroneos are grateful to Prof. F. Innoccenti (Pisa) for making available the XRF facilities. A. Liati acknowledges the help of N. Rayner and W. Davis, GSC Ottawa, during different stages of the SHRIMP analytical work. The SHRIMP work of A. Liati was supported by a grant of the Swiss National Science Foundation (20-63767.00). We thank Prof. Dr. R. Altherr and an anonymous reviewer for constructively critisizing this paper.

\section{References}

Batchelor, R.A., and Bowden, P., 1985. Petrogenetic interpretation of granitoid rock series using multicationic parameters, Chem. Geol., 48, 43-55.

Chappell, B. W., and White, A. J. R., 1974. Two contrasting granite types, Pacific Geol., 8, 173 174.

Christofides, G., Koroneos, A., Liati, A., and Kral, J., 2006. Geochronology of the Kerkini granitic complex (Serbomacedonian massif, N. Greece) and geodnamic implications, Proc. of the XVIII congress of the Carpathian-Balkan Association, Belgrade, Serbia, 3-6 September, 61-64.

Christofides, G., D’Amico, C., Del Moro, A., Elefteriadis, G., and Kyriakopulos, C., 1990. Rb/Sr geochronology and geochemical characters of the Sithonia plutonic complex (Greece), Eur. J. Mineral., 2, 79-87.

Christofides, G., Koroneos, A., Pe-Piper, G., Katirtzoglou, K., and Chatzikirkou, A., 1999. PreTertiary A-type magmatism in the Serbomacedonian massif (N. Greece): Kerkini granitic complex, Bull. Geol. Soc. Greece, XXXIII, 131-148.

Christofides, G., Koroneos, A., Soldatos, T., and Eleftheriadis, G., 2000. Mesozoic magmatism in the area between the Vardar (Axios) zone and the Serbo-Macedonian massif (Northern Greece). In S. Karamata and S. Jankovic (eds), Proceedings of the International Symposium on Geology and Metallogeny of the Dinarides and the Vardar zone, 111-120. Banja Luka. Academy of Sciences and Arts of The Republic of Republic of Srpska. 537pp. 
Clemens, J.D., Holloway, J.R., and White, A.J.R., 1986. Origin of an A-type granite: Experimental constraints, Amer. Miner., 71, 317-324.

Collins, W.J., Beams, S.D., White, A.J.R., and Chappell, B. W., 1982. Nature and origin of A-type granites with particular reference to southeastern Australia, Contib. Mineral. Petrol., 80, 189-200.

Creaser, R.A., Price, R.C., and Worlmald, R.J., 1991. A-type granite revisited: assessement of residual source model, Geology, 19, 163-166.

de Wet, A.P., 1989, Geology of part of the Chalkidiki Peninsula, Northern Greece, PhD thesis, Cambridge, Wolfson College, 177pp.

de Wet, A.P., Miller, J.A., Bickle, M.J., and Chapman, H.J., 1989. Geology and geochronology of the Arnea, Sithonia and Ouranopolis intrusions, Chalkidiki Peninsula, Northern Greece, Tectonophysics, 161, 65-79.

Debon, F., and Le Fort, P., 1983. A chemical-mineralogical classification of commoc plutonic rocks and associations, Trans. R. Soc. Edinburgh:Earth Sci., 73, 135-149.

Dimitriadis, S., and Asvesta, A., 1993. Sedimentation and magmatism related to the Triassic rifting and later events in the Vardar-Axios zone, Bull. Geol. Soc. Greece, XXVIII/2, 149-168.

Dixon, J.E., and Dimitriadis, S., 1984. Metamorphosed ophiolitic rocks from the SerboMacedonian Massif near Lake Volvi, north-east Greece. In J. E Dixon and A. H. E.Robertson (eds), The geological evolution of eastern Mediterranean, Geol. Soc. (London), Spec. Publ., 17, 603-618.

Eby, G. N., 1990, The A-type granitoids: A review of their occurrence and chemical characteristics and speculations on their petrogenesis, Lithos, 26, 115-134.

Eby, N., 1992. Chemical subdivision of the A-typr granitoids: Petrogenetic and tectonic implications, Geology, 20, 641-644.

Frei, R., 1992. Isotope ( $\mathrm{Pb}, \mathrm{Rb}-\mathrm{Sr}, \mathrm{S}, \mathrm{O}, \mathrm{C}, \mathrm{U}-\mathrm{Pb})$ geochemical investigations on Tertiary intrusives and related mineralizations in the Serbomacedonian $\mathrm{Pb}-\mathrm{Zn}, \mathrm{Sb}+\mathrm{Cu}-\mathrm{Mo}$ metallogenic province in Northern Greece, PhD thesis, Zürich, Switzerland, Swiss Federal Institute of Technology (ETH), 231pp.

Kostopoulos, D.K., Reischmannn, T., and Sklavounos, S. A., 2001. Palaeozoic and Early Mesozoic magmatism and metamorphism in the Serbo-Macedonian massif, Central Macedonia, Northern Greece, European Union of Geosciences, Abstracts, LS03: Tham 01:F2, 318.

Landenberger, B., and Collins, W.J., 1996. Derivation of A-type granites from a dehydrated charnockitic lower crust: evidence from the Chaelundi complex, Eastern Australia, J. Petrol., $37,1,145-170$.

Liati, A., and Fanning, C.M., 2005. Eclogites and their country rock orthogneisses in East Rhodope representing Upper Permian gabbros and Upper Carboniferous granitoids: Geochronological constraints, Abstracts of the $7^{\text {th }}$ International Eclogite Conference, Graz, Austria.

Loiselle, M.C., and Wones, D.R., 1979. Characteristics and origin of anorogenic granites, Geol. Soc. Amer. Abstr. Programs, 11, 468.

Miller, F.C., Stoddard, F.E., Bradfish, J.L., and Dollase, A.W., 1981. Composition of plutonic muscovite: genetic implications, Can. Mineral., 19, 25-34. 
Mohamed, F.H., Moghazi, A.M., and Hassanen, M.A., 1999. Petrogenesis of Late Proterozoic granitoids in the ras Gharib magmatic province, northern Eastern Desert, Egypt: petrological and geochemical constraints, N. Jb. Miner. Abh., 174, 319-353.

Papadopoulos, C., and Kilias, A., 1985. Altersbeziehungen zwischen Metamorphose und Deformation im Teil Serbomazedonischen Massivs (Vertiskos Gebirge, North-Griechenland), Geol. Rundsch., 74, 77-85.

Pearce, J.A., Harris, N.B.W., and Tindle, A.C., 1984. Trace element discrimination diagrams for the tectonic interpretation of granitic rocks, J. Petrol., 25, 956-983.

Pe-Piper, G., and Piper, D.J.W., 2002. The igneous rocks of Greece: the anatomy of an orogen, Berlin, Borntraeger, 645pp.

Sakellariou, D., 1989. Geologie des Serbomazedonischen Massivs in der Nordoestlichen Chalkidi$k i$, N. Griechenland - Deformation und Metamorphose, Diss. Mainz Univ., Geol. Monographs N. 2, Dept of Geology Univ. Athens, 177pp.

Schleicher, H., and Lippolt, H.J., 1981. Magmatic muscovite in felsitic parts of rhyolites from Southwest Germany, Contrib. Mineral. Petrol., 78, 220-224.

Skjerlie, K.P., and Johnston, D.A., 1993. Fluid-absent melting behaviour of an F-rich tonalitic gneiss at mid-crustal pressures: implications for the generation of anorogenic granites, $J$. Petrol., 34,4, 785-815.

Stern, R., 1997. The GSC Sensitive High Resolution Ion Microprobe (SHRIMP): analytical techniques of zircon $\mathrm{U}-\mathrm{Th}-\mathrm{Pb}$ age determinations and performance evaluation. In Radiogenic Age and isotope studies: Report 10.1-31, Geological Survey of Canada, Current research.

Tera, F., and Wasserburg, G.J., 1972, U-Th-Pb systematics in three Apollo 14 basalts and the problem of initial Pb in lunar rocks, Earth Planet. Sci. Lett., 14, 281-304.

Whalen, J.B., Currie, K.L., and Chappel, B.W., 1987. A-type granites: geochemical characteristics, discrimination and petrogenesis, Contrib. Mineral. Petrol., 95, 407-419.

White, A.J.R., and Chappell, B.W., 1977. Ultrametamorphism and granitoid genesis, Tectonophysics, 43, 7-22.

White, A.J.R., 1979. Sources of granite magmas, Geol. Soc. Amer. Abstr. Programs, 11, 539.

Wu, T.W., and Kerrich, R., 1986. Combined oxygen-isotope - compositional studies of some granitoids from the Grenville Province of Ontario, Can. J. Earth Sci., 23, 1412-1432.

Wu, F., Sun. D., Li, H., Jahn, B., and Wilde, S., 2002. A-type granites in northeastern China: age and geochemical constraints on their petrogenesis, Chem. Geol., 187, 143-273.

Zen, E-An., 1988. Phase relations of peraluminous granitic rocks and their petrogenetic implicatios, Ann. Rev. Earth Planet Sci., 16, 21-51.

Zhou, T., Yuan, F., Tan, L., Fan, Y., and Yue, S., 2006. Geodynamic significance of the A-type granites in the Sawuer region in west Junggar, Xinjiang: Rock geochemistry and SHRIMP zircon age evidence, Sci. in China Series D (Earth Sci.), 49,2, 113-123. 